Article

\title{
Effects of Buffer Gas Composition on Autoignition of Dimethyl Ether
}

\author{
Zhicheng Shi ${ }^{1,2}$, Hongguang Zhang ${ }^{1,2, *}$, Hao Liu ${ }^{1,2}$, Haitao Lu ${ }^{1,2}$, Jiazheng Li ${ }^{1,2}$ \\ and Xiang Gao ${ }^{1,2}$
}

1 College of Environmental and Energy Engineering, Beijing University of Technology, Pingleyuan No. 100, Beijing 100124, China; E-Mails: 15933731855@163.com (Z.S.); liuhao_0225@163.com (H.L.); 13641375795@163.com (H.L.); lijiazheng52946@sina.cn (J.L.); gxbjut0812@163.com (X.G.)

2 Collaborative Innovation Center of Electric Vehicles in Beijing, Pingleyuan No. 100, Beijing 100124, China

* Author to whom correspondence should be addressed; E-Mail: zhanghongguang@bjut.edu.cn; Tel.: +86-10-6739-2469; Fax: +86-10-6739-2774.

Academic Editor: Pierre Trambouze

Received: 25 August 2015 / Accepted: 11 September 2015 / Published: 17 September 2015

\begin{abstract}
Experimental and numerical studies are conducted on the thermal, chemical and dilution effects of buffer gas composition on autoignition of dimethyl ether (DME). The buffer gases considered are nitrogen $\left(\mathrm{N}_{2}\right)$, a mixture of $\mathrm{N}_{2}$ and argon (Ar) at a mole ratio of $50 \% / 50 \%$ and a mixture of $\mathrm{Ar}$ and carbon dioxide $\left(\mathrm{CO}_{2}\right)$ at a mole ratio of $61.2 \% / 38.8 \%$. Experiments are performed using a rapid compression machine (RCM) at compressed pressure of 10 bar, equivalence ratio $(\varphi)$ of 1 , and compressed temperature from $670 \mathrm{~K}$ to $795 \mathrm{~K}$. The $\mathrm{N}_{2}$ dilution ratio considered ranges from $36.31 \%$ to $55.04 \%$. The experimental results show that buffer gas composition has little impact on the first-stage ignition delay. However, significant differences in the total ignition delay as a function of buffer gas composition are observed in the negative temperature coefficient (NTC) region. Compared to $\mathrm{N}_{2}, \mathrm{~N}_{2} / \mathrm{Ar}(50 \% / 50 \%)$ mixture decreases the total ignition delay by $31 \%$. The chemical effects of buffer gas composition on the first-stage and total ignition delays are negligible. With increasing $\mathrm{N}_{2}$ dilution ratio, the first-stage ignition delay slightly increases, while a significant increase in the total ignition delay is observed. Moreover, the NTC behavior of total ignition delay is noted to become more pronounced at high $\mathrm{N}_{2}$ dilution ratio. The heat release during the first-stage ignition decreases as $\mathrm{N}_{2}$ dilution ratio increases. Results of
\end{abstract}


numerical simulations with the Zhao DME mechanism over a wider range of temperature show good agreement with that of experiments. Further numerical simulations are conducted using pure $\mathrm{N}_{2}, \mathrm{Ar}$ and $\mathrm{CO}_{2}$ as buffer gases. Results indicate that the thermal effects are the dominant factor in low temperature and NTC regions. The chemical effects become pronounced in the NTC region, and the chemical effect of $\mathrm{CO}_{2}$ exceeds the thermal effect at the compressed temperature higher than $880 \mathrm{~K}$.

Keywords: buffer gas; dimethyl ether; ignition delay; rapid compression machine

\section{Introduction}

Exhaust gas recirculation (EGR) is widely used to control the combustion process and reduce $\mathrm{NO}_{x}$ emissions. The effects of EGR can be classified as thermal (changes in the heat capacity of the mixture), chemical (third-body collision efficiencies and dissociation of $\mathrm{CO}_{2}$ ) and dilution effects (changes in $\mathrm{O}_{2}$ concentration of the mixture). The combined effects of the three mechanisms play important roles in controlling combustion temperature, combustion rate and burn duration to influence combustion performance. However, the three mechanisms are often convolved. For example, both thermal effects and dilution effects will impact heat transfer rates. Therefore, it is difficult to isolate the effects of EGR composition under the condition of internal combustion engine (ICE) due to the complexities of the combustion and difficulties in controlling the test parameters. However, extensive studies are still conducted to investigate the thermal, chemical and dilution effects of buffer gases on the combustion process and exhaust gas emissions. Moreover, increasing attention has been paid to the ignition delay, which is one of the significant parameters for both combustion process optimization and development of kinetic mechanisms.

In the work by Ladommatos et al. [1], the authors separately studied the thermal, chemical and dilution effects of EGR on the ignition delay on a high-speed direct injection diesel engine. The authors found that the dilution effects have the largest impact on the ignition delay and exhaust gas emissions. They also noted that the ignition delay increases with increasing EGR. In the work by Pierpont et al. [2], a study was conducted to explore the effects of EGR on the $\mathrm{NO}_{x}$ emissions. They found that EGR increases the ignition delay, and thus better fuel-air mixing can be achieved, thereby resulting in the reduction of $\mathrm{NO}_{x}$. Li et al. [3] experimentally studied thermal and dilution effects of EGR components, including $\mathrm{N}_{2}$ and $\mathrm{CO}_{2}$, on combustion and $\mathrm{NO}_{x}$ emissions of a turbocharged natural gas SI engine. The authors found that, compared to thermal effects, dilution effects have a greater effect on the reduction of the $\mathrm{NO}_{x}$ emissions. Sjöberg and Dec [4] investigated the effects of EGR and its constituents on homogeneous charge compression ignition (HCCI) of ethanol. They found that EGR addition retards the autoignition timing for all five fuels studied, and the amount of retardation is dependent on the specific fuel type. Al-Qurashi et al. [5] successfully isolated and examined the thermal, chemical, and dilution effects of the $\mathrm{CO}_{2}$ (approximately simulate EGR) on soot reactivity in a diesel engine and a laminar co-flow ethylene diffusion flame. The authors reported that the magnitudes of three effects on the soot reactivity rank thermal effect (45\%) as most important, dilution effect (35\%) second, and chemical effect $(20 \%)$ as the least important. Cairns et al. [6] studied the effects of EGR in a multi-cylinder 
research engine. The authors found that EGR increases the ignition delay and decreases the heat release during ignition, and then effectively suppresses engine knock. Kiplimo et al. [7] studied the effects of EGR on combustion and emission characteristics of a diesel premixed charge compression ignition (PCCI) engine. They found that EGR leads to extended ignition delay which is essential in mixture formation before ignition, improved indicated mean effective pressure (IMEP) and hence improved thermal efficiency. Ladommatos et al. [8] separately studied the thermal, chemical and dilution effects of $\mathrm{CO}_{2}$ on engine combustion and emissions. The authors found that $\mathrm{CO}_{2}$ addition increases the ignition delay, and then affects both $\mathrm{NO}_{x}$ and soot emissions. They also noted that the chemical effect of $\mathrm{CO}_{2}$ has small but measurable effects on exhaust emissions, while the thermal effect has only a small effect on exhaust emissions.

Buffer gases are also widely used to control test conditions in fundamental combustion researches [9-13]. The composition of buffer gases affects the heat capacity of the gas mixture, three-body collision efficiencies and concentrations of fuel and $\mathrm{O}_{2}$. A number of studies also focus on the effects of buffer gas composition on combustion characteristic in fundamental combustion facilities. In the work by Shen et al. [9], the authors studied the influences of diluent gases on iso-octane ignition in shock tube (ST). They found that, compared to $\mathrm{N}_{2}$, Ar reduces the ignition delay of iso-octane by $20 \%$. Würmel et al. [10] studied the effects of diluent gases on ignition delay in rapid compression machine (RCM) and ST. The authors found that the Ar accelerates the ignition in ST, but decelerates ignition in RCM, which is caused by the differences in the thermal conductivity and heat capacity among different buffer gases. Yu et al. [11] investigated the effects of several EGR components on the autoignition of natural gas in RCM. They observed that $\mathrm{CO}_{2}$ and water addition at low mole fraction has no impact on the ignition delay of natural gas. Davidson et al. [12] modeled the iso-octane ignition using two different models with $\mathrm{N}_{2}$ and Ar as buffer gases. They observed significant differences in ignition delay using the model by Pitsch et al., whereas for the model by Davis and Law the differences are insignificant. Wagnon and Wooldridge [13] quantified the chemical kinetic and thermal effects of buffer gas composition on autoignition of iso-octane, $n$-heptane, and $n$-butanol. The simulation results revealed that the buffer gas composition has significant impact on the total ignition delay in the temperature coefficient (NTC) region. While outside the NTC region, the buffer gas effects are small.

Dimethyl ether (DME) becomes one of the most promising alternative fuels due to its high heating value and cetane number, and thus excellent autoignition characteristics [14]. Meanwhile, lots of studies have also been conducted to investigate the effects of buffer gases on the autoignition of DME using both ICEs and fundamental combustion facilities [15-21], but they only highlight the overall effects of buffer gas composition. Isolating as much as possible the effects of buffer gas composition will help to understand the specific impact mechanism. RCM, one of the fundamental combustion facilities, is an ideal experimental platform for ignition and combustion research and convenient to control the various parameters in experiments, thus the effects of buffer gases can be easily and independently studied. As a consequence, experiments and numerical simulations are conducted to isolate and quantify thermal, chemical and dilution effects of buffer gas composition on the autoignition of DME in this study using a RCM. 


\section{Experimental}

\subsection{Rapid Compression Machine}

The RCM (Beijing University of Technology, Beijing, China) used in this study has been introduced in a previous paper [22], and only a brief overview will be given here. The RCM is mainly composed of pneumatic drive, hydraulic control, reactor cylinder, gas supply, and data acquisition systems. The driver cylinder and reactor cylinder have bores of $200 \mathrm{~mm}$ and $50 \mathrm{~mm}$, respectively, and driving gas pressure is $2-8$ bar. The compression ratio $(\varepsilon)$ can be altered in the range of $8.42-16.9$ by adjusting the number of stroke spacers and clearance spacers. The mixture in the reactor cylinder is compressed by a rapidly moving piston and then it ignites spontaneously (autoignition) at the end of compression. As used in many RCMs [23-29], a creviced piston is used to suppress boundary vortex caused by the movement of the piston and to maintain well-defined homogeneous conditions in the reactor cylinder. As a result, the "adiabatic core" hypothesis can be used more accurately, and the compressed temperature can be calculated using the following equation:

$$
\int_{T_{0}}^{T_{c}} \frac{\gamma}{\gamma-1} \frac{\mathrm{d} T}{T}=\ln \left(\frac{P_{c}}{P_{0}}\right)
$$

where $P_{0}$ and $T_{0}$ are initial pressure and initial temperature, $P_{\mathrm{c}}$ and $T_{\mathrm{c}}$ are compressed pressure and compressed temperature at the top dead center (TDC), $\gamma$ is the ratio of specific heat of the mixture, which is the function of temperature and composition of mixture.

The schematic diagram of the RCM test bench is shown in Figure 1.

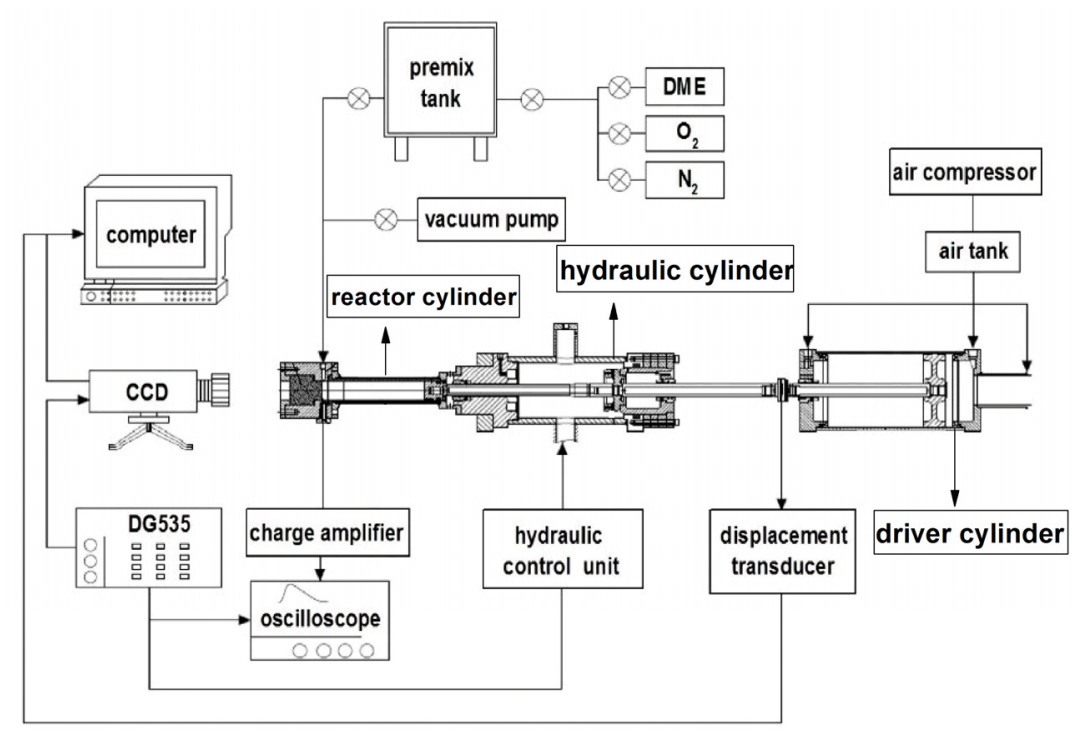

Figure 1. Schematic diagram of the rapid compression machine (RCM) test bench.

\subsection{Definition of Ignition Delay and Repeatability of Experiments}

Pressure-time histories from the experiments are used to determine ignition delay. In this study, the time zero is taken as the end of the compression stroke, when the pressure peaks. Generally, DME shows the well-known two-stage ignition delay and two-stage combustion characteristics. Here, the first-stage ignition delay ( $\tau_{1}$ as shown in Figure 2 ) is defined as the time between the end of compression stroke and 
first maximum in the rate of pressure rise during ignition. The second-stage ignition delay ( $\tau_{2}$ as shown in Figure 2) is defined as the time from first maximum to second maximum in the rate of pressure rise, and the total ignition delay $\tau$ is the sum of $\tau_{1}$ and $\tau_{2}$. As shown in Figure 3, single-stage ignition delay and single-stage combustion occur at high compressed temperature. Then, the total ignition delay is defined as the time from the end of compression stroke to the time corresponding to the maximum in the rate of pressure rise during ignition.

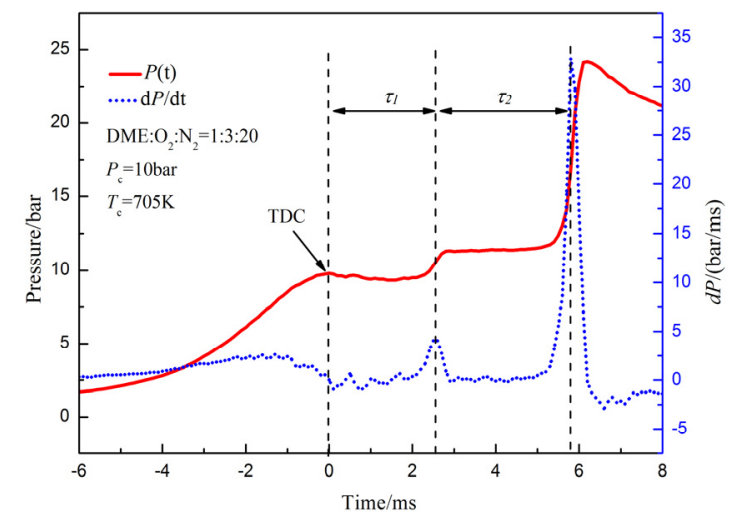

Figure 2. Definition of ignition delay: two-stage ignition delay and two-stage combustion.

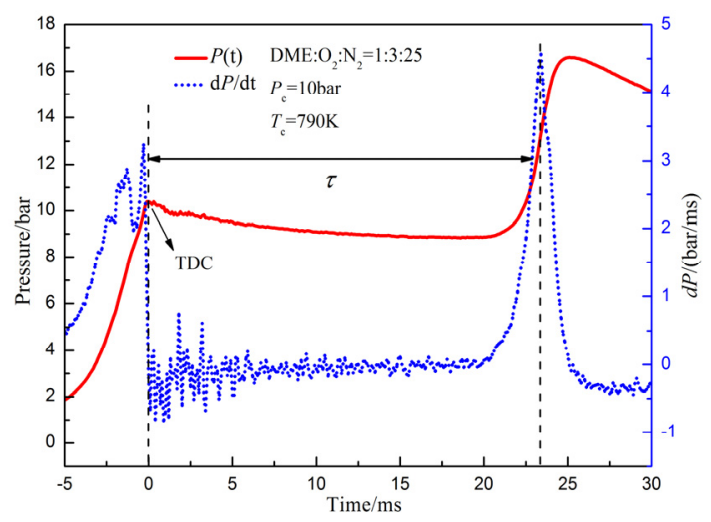

Figure 3. Definition of ignition delay: single-stage ignition delay and single-stage combustion.

As seen in Figure 4, overlapping pressure traces follow each other closely under the same test conditions, demonstrating that the repeatability of experiments in this study can be ensured.

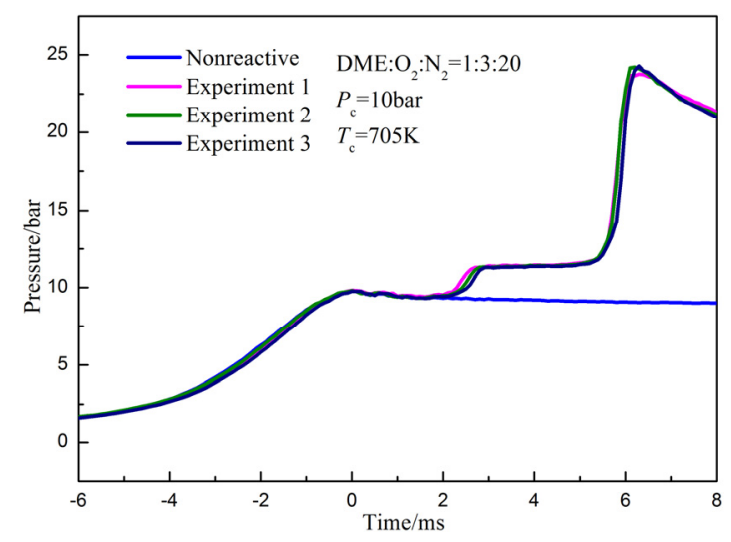

Figure 4. Experimental repeatability of compression and autoignition process. 


\subsection{Preparation of Gas Mixture}

The gas mixture is prepared in a premix tank. The purities of gases used are as follows: DME, 99.5\%; oxygen $\left(\mathrm{O}_{2}\right), 99.999 \% ; \mathrm{N}_{2}, 99.999 \% ; \mathrm{Ar}, 99.999 \% ; \mathrm{CO}_{2}, 99.999 \%$. The premix tank and pipelines are evacuated before introducing the mixture components using a vacuum pump. Based on partial pressures method, the experimental gases are filled into the premix tank and stirred for at least $30 \mathrm{~min}$. After stirring $30 \mathrm{~min}$, the gas mixture is left to homogenize overnight.

Typical buffer gases including $\mathrm{N}_{2}$, Ar, and $\mathrm{CO}_{2}$ are widely used in RCMs to achieve desired experimental conditions. Ar, a monoatomic gas with high ratio of specific heat and low heat capacity, is widely used to extend the range of compressed temperature upward, while $\mathrm{CO}_{2}$, a polyatomic gas present in EGR, extends the range of compressed temperature downward.

Consequently, in this study, the considered buffer gases are $\mathrm{N}_{2}$, a mixture of $\mathrm{N}_{2}$ and $\operatorname{Ar}(50 \% / 50 \%)$ and a mixture of $\mathrm{Ar}$ and $\mathrm{CO}_{2}(61.2 \% / 38.8 \%)$. Here, the heat capacity of the $\mathrm{Ar} / \mathrm{CO}_{2}(61.2 \% / 38.8 \%)$ mixture is approximately identical to that of pure $\mathrm{N}_{2}$.

\subsection{Experimental Conditions}

In this study, the compressed pressure is changed by altering the initial pressure, and the compressed temperature is changed by adjusting the compression ratio and initial temperature. Pressure-time data are measured using a Kistler 6125C pressure transducer (Kistler, Winterthur, Switzerland) and a Kistler 5011 charge amplifier (Kistler, Winterthur, Switzerland), and recorded by a Tektronix MS04000 oscilloscope (Tektronix, Johnston, OH, USA).

The experimental conditions in this study are shown in Table 1.

Table 1. Experimental conditions.

\begin{tabular}{ccccc}
\hline Mole proportion & Dilution ratio (\%) & $\boldsymbol{\varphi}$ & $\boldsymbol{P}_{\mathbf{c}}(\mathbf{b a r})$ & $\boldsymbol{T}_{\mathbf{c}}(\mathbf{K})$ \\
\hline Dimethyl ether (DME): $\mathrm{O}_{2}: \mathrm{N}_{2}=1: 3: 20$ & 36.31 & & & \\
DME: $\mathrm{O}_{2}: \mathrm{N}_{2}: \mathrm{Ar}=1: 3: 10: 10$ & 36.31 & & & \\
DME: $\mathrm{O}_{2}: \mathrm{Ar}_{\mathrm{CO}_{2}=1: 3: 12.245: 7.755}$ & 36.31 & 1 & 10 & $670-795$ \\
DME: $\mathrm{O}_{2}: \mathrm{N}_{2}=1: 3: 25$ & 47.29 & & & \\
DME: $\mathrm{O}_{2}: \mathrm{N}_{2}=1: 3: 30$ & 55.04 & & & \\
\hline
\end{tabular}

\section{Numerical Simulations}

Numerical simulations are conducted using CHEMKIN-PRO software. Due to the very short compression time and low temperature in the reactor cylinder, the heat loss during compression is negligible. However, the temperature in the reactor cylinder increases when the piston reaches the TDC and the heat loss to the reactor cylinder wall increases. Therefore, in order to obtain better simulation results, the heat loss after compression must be taken into account. In this study, a method developed by Mittal and Sung [30], which uses an increase of volume to represent the heat loss after compression, is adopted to simulate the experimental data of RCM. To determine the volume change due to heat loss for a given reactive mixture, a non-reactive experiment should be first conducted using gas mixture with the same heat capacity, initial pressure, and initial temperature as the reactive mixture. As shown in Figure 4, 
for both compression and post-compression events before ignition, the pressure trace of a nonreactive mixture matches very well with that of the reactive mixture, proving the applicability of the heat transfer model. Based on the analysis above, in this study, the simulations are performed using a homogeneous batch reactor with varying volume. The compressed pressure and compressed temperature in the reactor cylinder are used for setting the initial conditions of simulations.

The Zhao DME mechanism [31] containing 55 species and 290 reactions is used for simulations in this study, which has been validated for a wide range of physical conditions, including jet-stirred reactors [32], shock tubes [33], laminar flame speeds [34] and RCMs [35].

\section{Results and Discussion}

\subsection{Thermal and Chemical Effects of Buffer Gas Composition}

Variation of the first-stage and total ignition delays with buffer gas composition is shown in Figure 5. The Zhao DME mechanism consistently over-predicts the first-stage ignition delay in the temperature range studied. Moreover, larger differences in the first-stage ignition delay between experimental data and model predictions are observed with increasing compressed temperature. The differences are due to the fact that the compressed temperature is controlled by preheating the mixture in experiments, resulting in the occurrence of a reaction during compression. Both experimental and simulation results show that the buffer gas composition has little impact on the first-stage ignition delay.

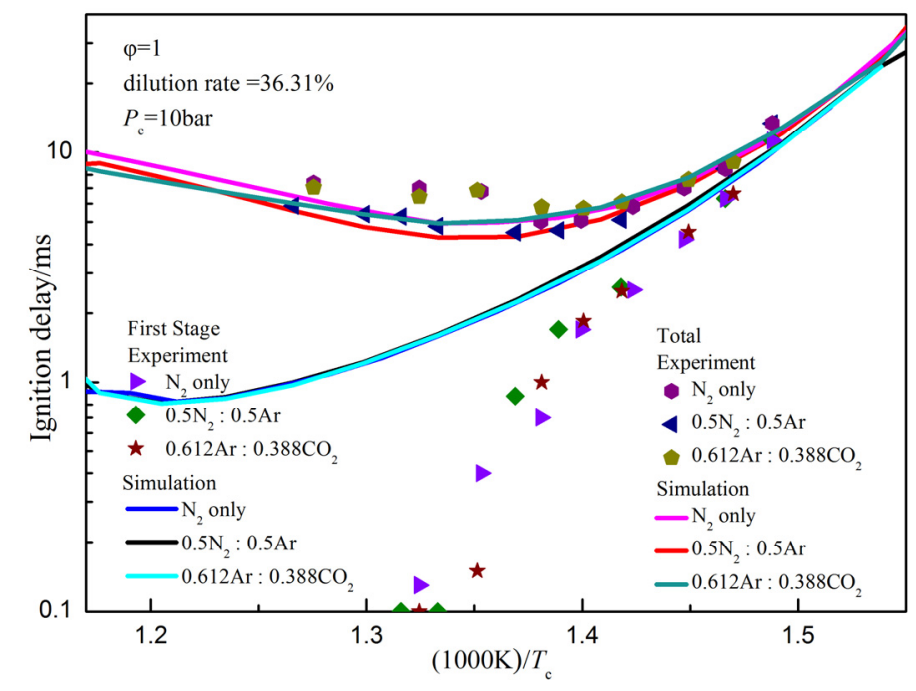

Figure 5. Experimental and simulation results of effects of buffer gas composition on first-stage and total ignition delays.

Figure 6 shows the typical pressure traces from experiments using the $\mathrm{N}_{2}, \mathrm{~N}_{2} / \operatorname{Ar}(50 \% / 50 \%)$ mixture and $\mathrm{Ar} / \mathrm{CO}_{2}(61.2 \% / 38.8 \%)$ mixture respectively as buffer gases at the compressed temperature of $705 \mathrm{~K}$. $\mathrm{N}_{2} / \operatorname{Ar}(50 \% / 50 \%)$ mixture shows a slower pressure rise during the compression process. The main reason is that the $\mathrm{N}_{2} / \mathrm{Ar}(50 \% / 50 \%)$ mixture has a high ratio of specific heat, then smaller compression ratio and initial pressure are adopted to achieve the same compressed pressure and temperature. Simulation results are shown in Figure 7; the compression process is simulated in particular for comparison with Figure 6. 


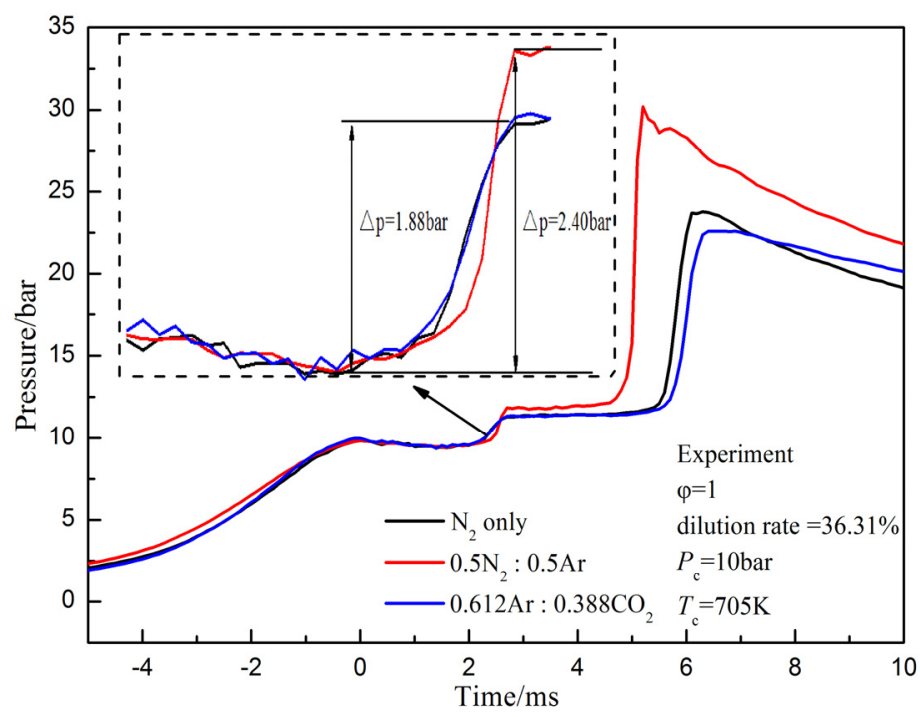

Figure 6. Comparison of effects of buffer gas composition on the dimethyl ether (DME) ignition process (experimental results).

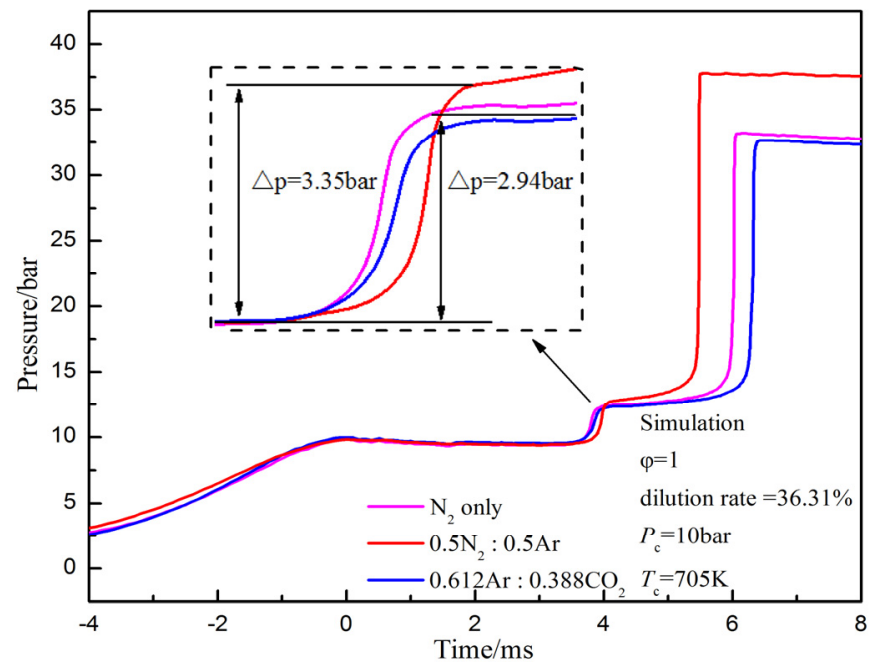

Figure 7. Comparison of effects of buffer gas composition on DME ignition process (simulation results).

Both the experimental data and model predictions demonstrate that the first-stage ignition delay shows no sensitivity to the buffer gas composition. However, significant differences in pressure and temperature rise during first-stage ignition are observed, which is caused by the differences in buffer gas heat capacity. The $\mathrm{N}_{2} / \operatorname{Ar}(50 \% / 50 \%)$ mixture exhibits a higher increase in pressure and temperature after the first-stage ignition. This is because $\mathrm{N}_{2}$ exhibits the higher accumulated heat release [36], but Ar has a smaller heat capacity which dominates the pressure and temperature rise. The general trends of experimental and simulation results for pressure and temperature rise during the first-stage ignition are consistent. For experiments, $\mathrm{N}_{2}$ exhibits a 1.88 bar increase in pressure and $131 \mathrm{~K}$ increase in temperature; $\mathrm{N}_{2} / \mathrm{Ar}(50 \% / 50 \%)$ mixture exhibits a 2.40 bar increase in pressure and $168 \mathrm{~K}$ increase in temperature. For simulations, the pressure rise of $\mathrm{N}_{2}$ is about 2.94 bar, corresponding to about $204 \mathrm{~K}$ rise in temperature; the pressure rise of $\mathrm{N}_{2} / \mathrm{Ar}(50 \% / 50 \%)$ mixture is about 3.35 bar, corresponding to about $234 \mathrm{~K}$ rise in temperature. Two factors contribute to the differences in the experimental and simulation 
data. First, the mass transfer between gases in the reactor cylinder and the crevice volume at the end of compression are negligible in numerical simulations. Second, it is difficult to achieve absolute homogeneous ignition in experiments.

It is also seen from Figure 5 that for the total ignition delay, there is a good agreement between the measurements and model predictions. The NTC behavior of total ignition delay is observed for both measurements and model results in the compressed temperature range studied. As shown in Figure 5, the buffer gas composition has little impact on the total ignition delay in the low temperature range; however, the significant differences in the total ignition delay are observed in the NTC region, especially at the starting point of the NTC region. Compared to the $\mathrm{N}_{2}, \mathrm{~N}_{2} / \mathrm{Ar}(50 \% / 50 \%)$ mixture, there are decreases in the total ignition delay by $31 \%$ and $14 \%$ for experimental and simulation data, respectively.

Figure 8 shows the variation of the second-stage ignition delay and pressure rise during the first-stage ignition with compressed temperature under the same conditions shown in Figure 5. The general trends of measurements and model predictions are consistent. As has been established, the pressure rise during the first-stage ignition is caused by the heat release. In this study, we use the pressure rise to approximately represent the heat release during the first-stage ignition. Both experimental and simulation results show that the heat release during the first-stage ignition decreases with increasing compressed temperature, whereas the second-stage ignition delay increases. Additionally, as shown in Figure 9, differences in heat release between $\mathrm{N}_{2}$ and the $\mathrm{N}_{2} / \operatorname{Ar}(50 \% / 50 \%)$ mixture become smaller with increasing compressed temperature. In the low temperature region, the two-stage ignition delay is observed, but the second-stage ignition delay is very short. Consequently, the impact of differences in heat release on the second-stage ignition delay is limited, although larger differences in heat release exist at low compressed temperature. As a consequence, the total ignition delay shows no sensitivity to the buffer gas composition in the low temperature region. Because in the NTC region differences in heat release during the first-stage ignition have a significant impact on the second-stage ignition delay, compared to $\mathrm{N}_{2}$, the total ignition delay of $\mathrm{N}_{2} / \operatorname{Ar}(50 \% / 50 \%)$ mixture has a larger reduction as shown in Figure 5. It is also noted that the temperatures corresponding to the intersection of the pressure rise traces and second-stage ignition delay traces shown in Figure 8 are approximately the same as those corresponding to the starting point of NTC region shown in Figure 5.

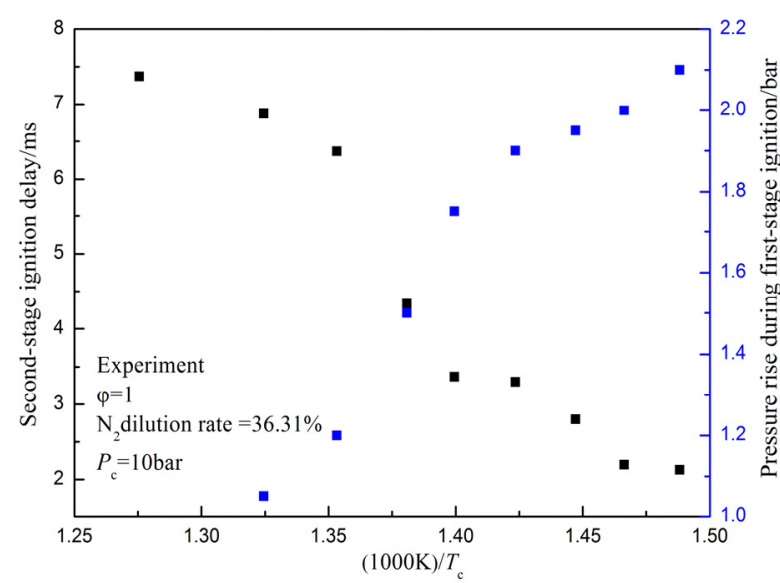

(a)

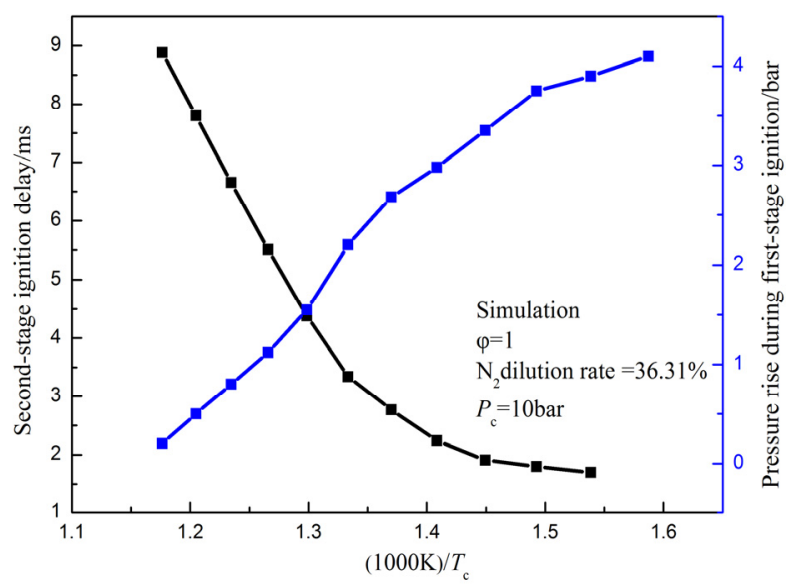

(b)

Figure 8. Variation of second-stage ignition delay and pressure rise during the first-stage ignition for $\mathrm{N}_{2}$ dilution: (a) experimental results; (b) simulation results. 


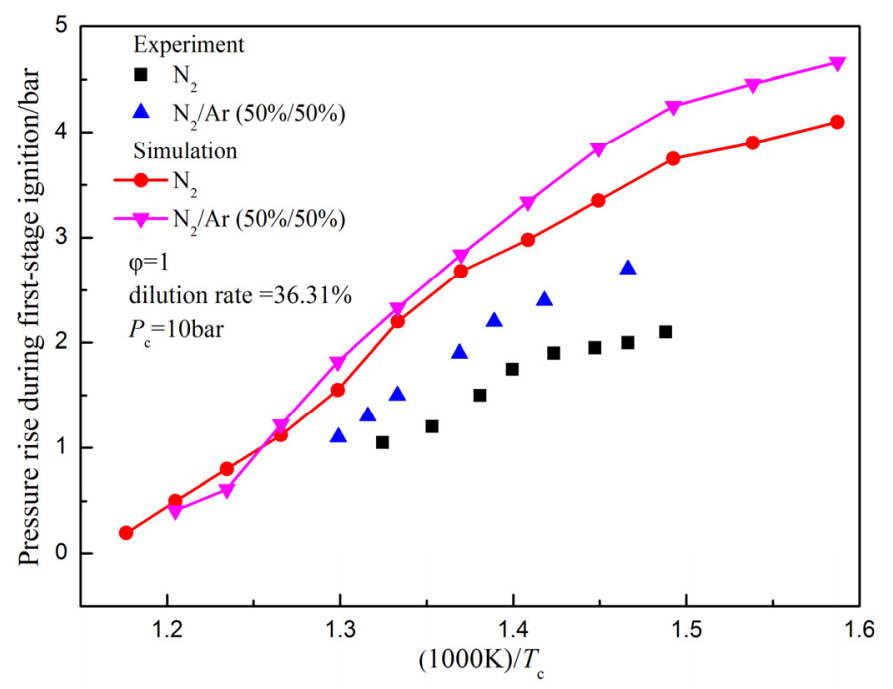

Figure 9. Experimental and simulation results of comparison of pressure rise during the first-stage ignition for $\mathrm{N}_{2}$ and $\mathrm{N}_{2} / \mathrm{Ar}(50 \% / 50 \%)$ mixture.

In order to isolate the chemical effects of buffer gas composition from the thermal effects, experiments and simulations are conducted using a mixture of $\mathrm{Ar}$ and $\mathrm{CO}_{2}(61.2 \% / 38.8 \%)$ as buffer gas, which has the same heat capacity as that of $\mathrm{N}_{2}$. This is demonstrated by the fact that the pressure trace of $\mathrm{N}_{2}$ and the pressure trace of $\mathrm{Ar} / \mathrm{CO}_{2}(61.2 \% / 38.8 \%)$ mixture almost overlap during the compression and ignition process shown in Figures 6 and 7. In Figure 5, from the comparison of the $\mathrm{N}_{2}$ and $\mathrm{Ar} / \mathrm{CO}_{2}$ $(61.2 \% / 38.8 \%)$ mixture, the conclusion can be drawn that the first-stage ignition delay appears to be independent of the chemical effects of buffer gas composition.

To further explain this issue, the sensitivity analysis of the first-stage ignition delay is conducted at the compressed temperature of $680 \mathrm{~K}, 750 \mathrm{~K}$ and $830 \mathrm{~K}$ as shown in Figure 10. For comparison, the sensitivity coefficients of ignition delays are normalized [37]; thus, a negative coefficient means that the corresponding reaction promotes ignition and vice versa. The first-stage ignition delay is most sensitive to the isomerization of $\mathrm{CH}_{3} \mathrm{OCH}_{2} \mathrm{O}_{2}$ and the $\beta$-scission of $\mathrm{CH}_{2} \mathrm{OCH}_{2} \mathrm{O}_{2} \mathrm{H}$. Although third-body collision reactions are involved, they are not the dominant factor in controlling the first-stage ignition in the temperature range studied. As a consequence, the chemical effects of buffer gas composition have little impact on the first-stage ignition delay, as observed in Figure 5.

Two major reactions involving third-body collision shown in Figure 10 are as follows: $\mathrm{H}+\mathrm{O}_{2}(+\mathrm{M})$ $<=>\mathrm{HO}_{2}(+\mathrm{M}) ; \mathrm{H}_{2} \mathrm{O}_{2}(+\mathrm{M})<=>2 \mathrm{OH}(+\mathrm{M})$. Table 2 provides the third-body collision coefficients of each reaction in this study for buffer gases. In the Zhao DME mechanism, typical third-body collision coefficients for $\mathrm{Ar} / \mathrm{CO}_{2}$ mixture are 2.09 and 1.87 times that of $\mathrm{N}_{2}$ for the two reactions, respectively.

Table 2. The collision coefficients of third-body reaction.

\begin{tabular}{ccccc}
\hline Reactions & $\mathbf{N}_{\mathbf{2}}$ & $\mathbf{A r}$ & $\mathbf{C O}_{\mathbf{2}}$ & $\mathbf{A r} / \mathbf{C O}_{\mathbf{2}}(\mathbf{6 1 . 2 \%} / \mathbf{3 8 . 8 \%})$ \\
\hline $\mathrm{H}+\mathrm{O}_{2}(+\mathrm{M})<=>\mathrm{HO}_{2}(+\mathrm{M})$ & 1 & 1 & 3.8 & 2.09 \\
$\mathrm{H}_{2} \mathrm{O}_{2}(+\mathrm{M})<=>2 \mathrm{OH}(+\mathrm{M})$ & 1 & 0.64 & 3.8 & 1.87 \\
\hline
\end{tabular}




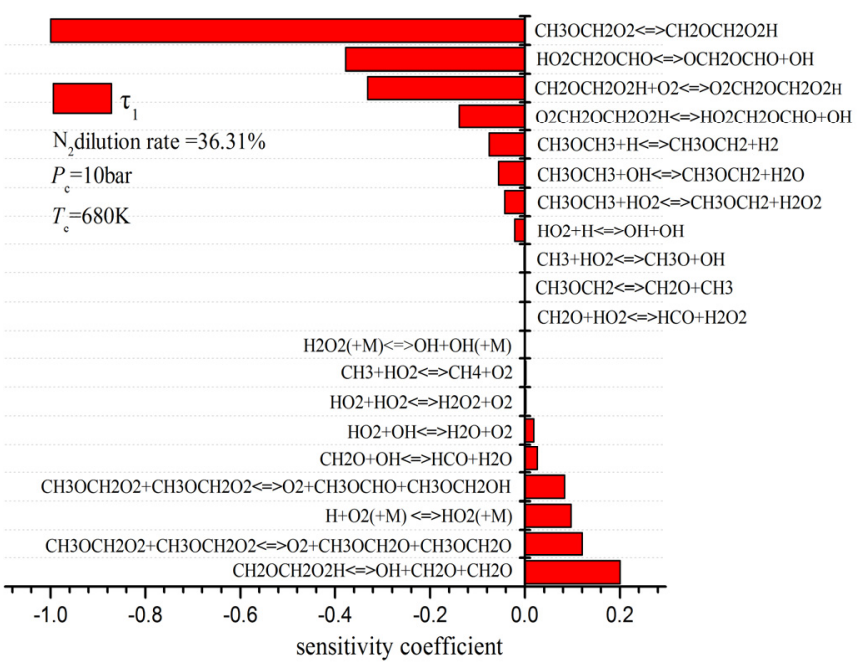

(a)

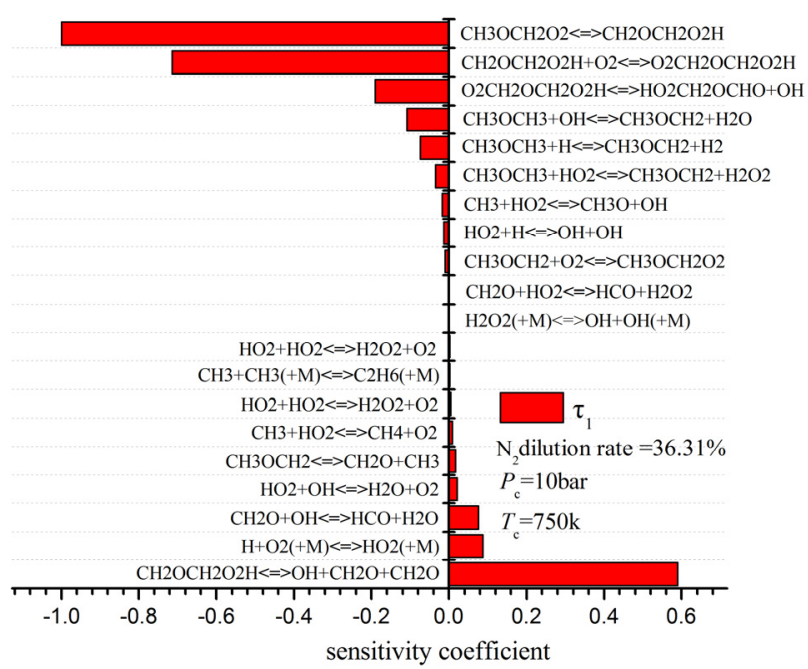

(b)

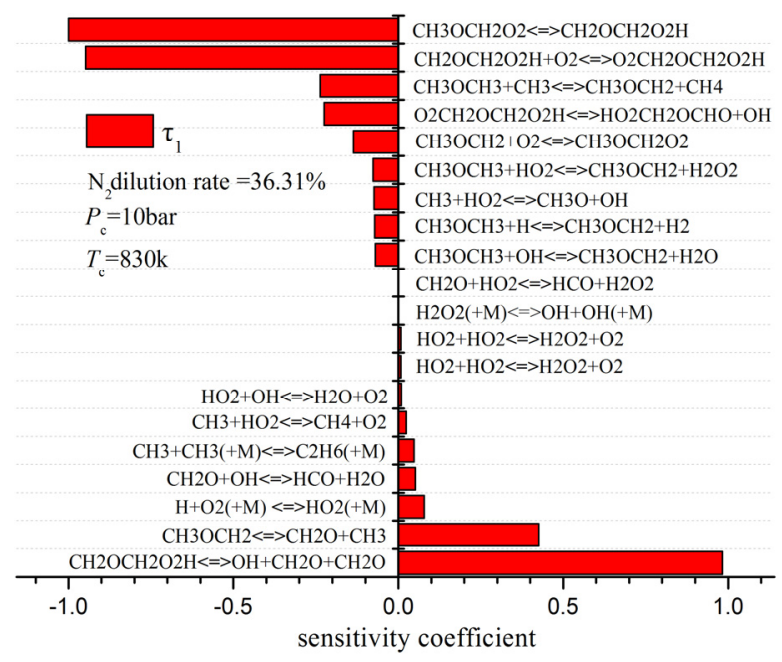

(c)

Figure 10. Sensitivity analysis for first-stage ignition delay: (a) $T_{\mathrm{c}}=680 \mathrm{~K}$; (b) $T_{\mathrm{c}}=750 \mathrm{~K}$; (c) $T_{\mathrm{c}}=830 \mathrm{~K}$.

As seen in Figure 5, for experiments, the total ignition delay using $\mathrm{Ar} / \mathrm{CO}_{2}(61.2 \% / 38.8 \%)$ mixture as buffer gases is almost the same as that of $\mathrm{N}_{2}$, indicating that change in third-body collision coefficients is not the dominant factor in controlling ignition in the compressed temperature range of 670-795 $\mathrm{K}$. The simulation results exhibit the same trends at the compressed temperature below $790 \mathrm{~K}$. However, above $790 \mathrm{~K}$, the total ignition delay of the $\mathrm{Ar} / \mathrm{CO}_{2}(61.2 \% / 38.8 \%)$ mixture is shorter than that of $\mathrm{N}_{2}$, thereby indicating that the chemical effects of buffer gas composition become pronounced.

To further investigate the thermal and chemical effects of buffer gas composition on the first-stage and total ignition delays, simulations are performed where the heat capacity of $\mathrm{N}_{2}$ is set to the same value as that of either $\mathrm{Ar}$ or $\mathrm{CO}_{2}$ using the constant volume adiabatic model at the compressed temperature of $740 \mathrm{~K}$ and $830 \mathrm{~K}$ [36]. As shown in Figure 11, the thermal effect indices are defined by $\Delta \tau_{\mathrm{t}, \mathrm{Ar}}\left(\tau_{\text {modifiedN2 }}-\tau_{\mathrm{N} 2}\right)$ and $\Delta \tau_{\mathrm{t}, \mathrm{CO} 2}\left(\tau_{\text {modifiedN2 }}-\tau_{\mathrm{N} 2}\right)$, which are the differences between the total ignition delay of the original $\mathrm{N}_{2}$ and the total ignition delay of modified $\mathrm{N}_{2}$ (same $C_{\mathrm{p}}$ as Ar) and modified $\mathrm{N}_{2}$ (same $C_{\mathrm{p}}$ as $\left.\mathrm{CO}_{2}\right)$, respectively. The chemical effect indices are defined by $\Delta \tau_{\mathrm{c}, \mathrm{Ar}}\left(\tau_{\mathrm{Ar}}-\tau_{\text {modifiedN2}}\right.$ ) and $\Delta \tau_{\mathrm{c}, \mathrm{CO} 2}\left(\tau_{\mathrm{CO} 2}-\tau_{\text {modifiedN2}}\right)$, which are the differences between the total ignition delay of the modified $\mathrm{N}_{2}$ and the total ignition delay of the corresponding $\mathrm{Ar}$ and $\mathrm{CO}_{2}$, respectively. 


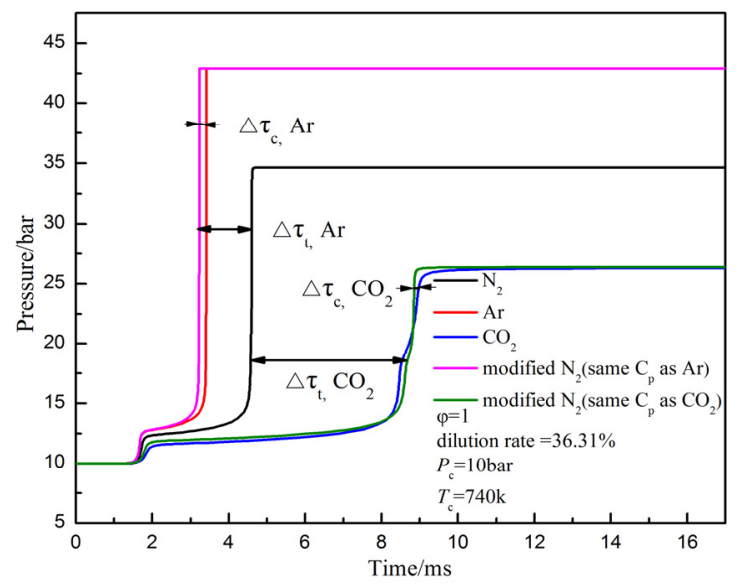

(a)

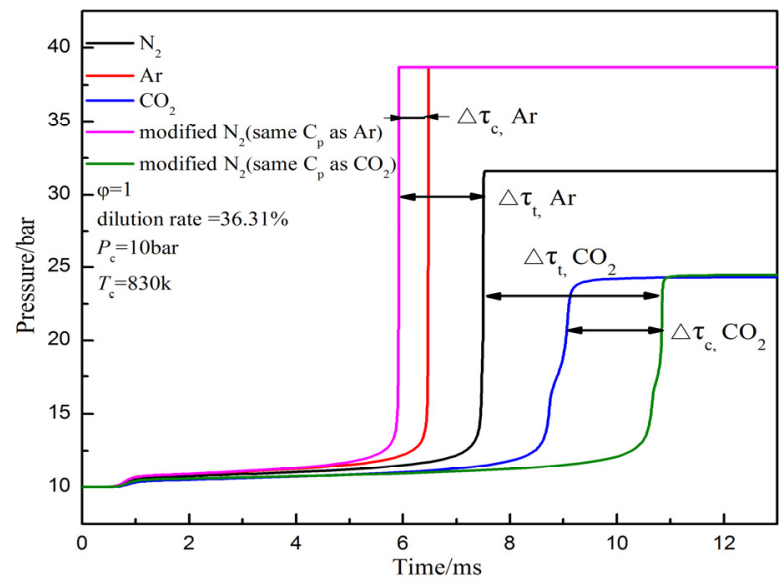

(b)

Figure 11. Simulation results of the thermal and chemical effects on DME ignition: (a) $T_{\mathrm{c}}=740 \mathrm{~K} ;$ (b) $T_{\mathrm{c}}=830 \mathrm{~K}$.

It is seen from Figure 11 that the thermal effect of Ar has little impact on the first-stage ignition delay. However, compared to $\mathrm{N}_{2}$, the thermal effect of Ar decreases the total ignition delay by $1.40 \mathrm{~ms}$ and $1.58 \mathrm{~ms}$ due to its lower heat capacity at the compressed temperature of $740 \mathrm{~K}$ and $830 \mathrm{~K}$, respectively. It is also noted that the pressure trace of modified $\mathrm{N}_{2}$ (same $C_{\mathrm{p}}$ as $\mathrm{Ar}$ ) and the pressure trace of Ar almost overlap before the second-stage ignition, which indicates that the impact of the chemical effect of Ar on the first-stage ignition delay is negligible. However, compared to $\mathrm{N}_{2}$, the chemical effect of Ar increases the total ignition delay by $0.18 \mathrm{~ms}$ and $0.55 \mathrm{~ms}$ due to its lower collision coefficients at the compressed temperature of $740 \mathrm{~K}$ and $830 \mathrm{~K}$, respectively.

Compared to $\mathrm{N}_{2}$, the thermal effect of $\mathrm{CO}_{2}$ increases the total ignition delay by $4.20 \mathrm{~ms}$ and $3.35 \mathrm{~ms}$ due to its higher heat capacity at the compressed temperature of $740 \mathrm{~K}$ and $830 \mathrm{~K}$, respectively. At the compressed temperature of $740 \mathrm{~K}$, both the first-stage ignition delay and the total ignition delay show no sensitivity to the chemical effect of $\mathrm{CO}_{2}$. At the compressed temperature of $830 \mathrm{~K}$, the chemical effect of $\mathrm{CO}_{2}$ also shows little impact on the first-stage ignition delay. However, the chemical effect of $\mathrm{CO}_{2}$ decreases the total ignition delay by $1.78 \mathrm{~ms}$ due to its higher collision coefficients which promote the ignition process.

As can be seen from the above analysis, the impact of thermal and chemical effects on the ignition delays varies with different compressed temperatures. Thus, in order to further quantify the thermal and chemical effects of buffer gas composition, simulations are conducted over a wide temperature range of 630-930 K as shown in Figures 12 and 13. Furthermore, the simulation results are normalized using the equation as follows: $\eta=\Delta \tau / \tau_{\text {total, }}$ where $\Delta \tau$ represent $\Delta \tau_{\mathrm{t}, \mathrm{Ar}}, \Delta \tau_{\mathrm{c}, \mathrm{Ar}}, \Delta \tau_{\mathrm{t}, \mathrm{CO} 2}$ and $\Delta \tau_{\mathrm{c}, \mathrm{CO} 2}$ mentioned above, $\tau_{\text {total }}$ represent the corresponding total ignition delays when $\mathrm{Ar}$ and $\mathrm{CO}_{2}$ are used as buffer gases.

As seen in Figures 12 and 13, the thermal and chemical effects of buffer gas composition have little impact on the first-stage ignition delay. In Figure 12, the thermal effect of Ar initially increases and then decreases with increasing compressed temperature. It is also noted that the temperature corresponding to the peak value of thermal effect of Ar is approximately equal to the temperature corresponding to the starting point of the NTC region. Meanwhile, the chemical effect of Ar becomes pronounced in the NTC region, but the magnitude is relatively small. Overall, the thermal effect of Ar is the dominant factor in the compressed temperature range studied. 


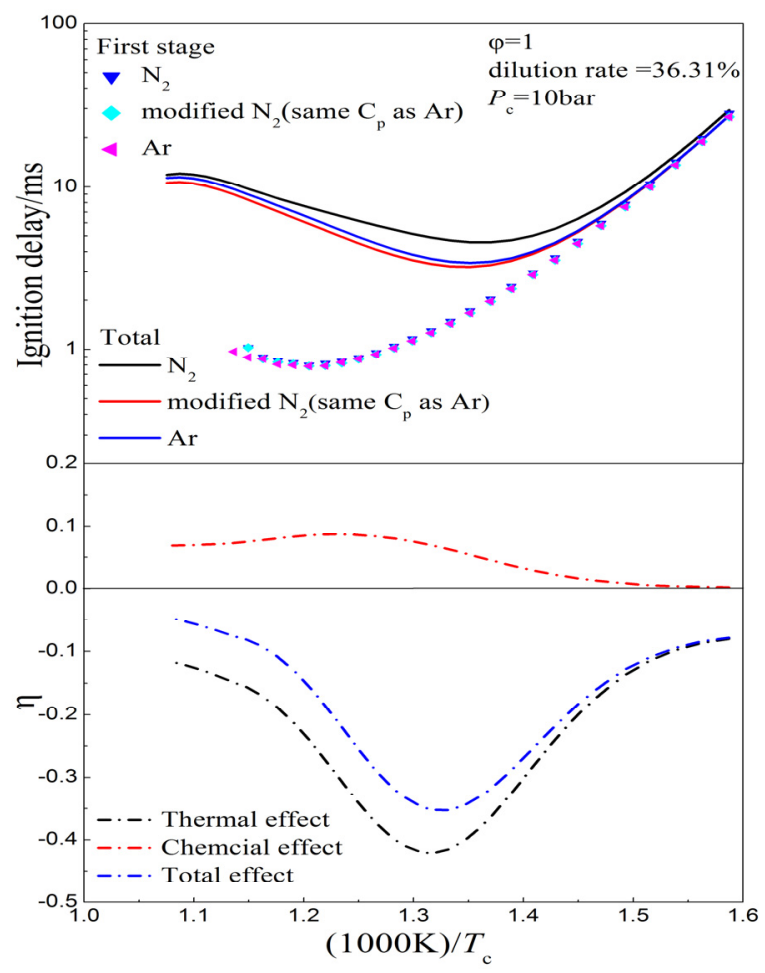

Figure 12. Comparison of the thermal and chemical effects of Ar on the first-stage and total ignition delays.

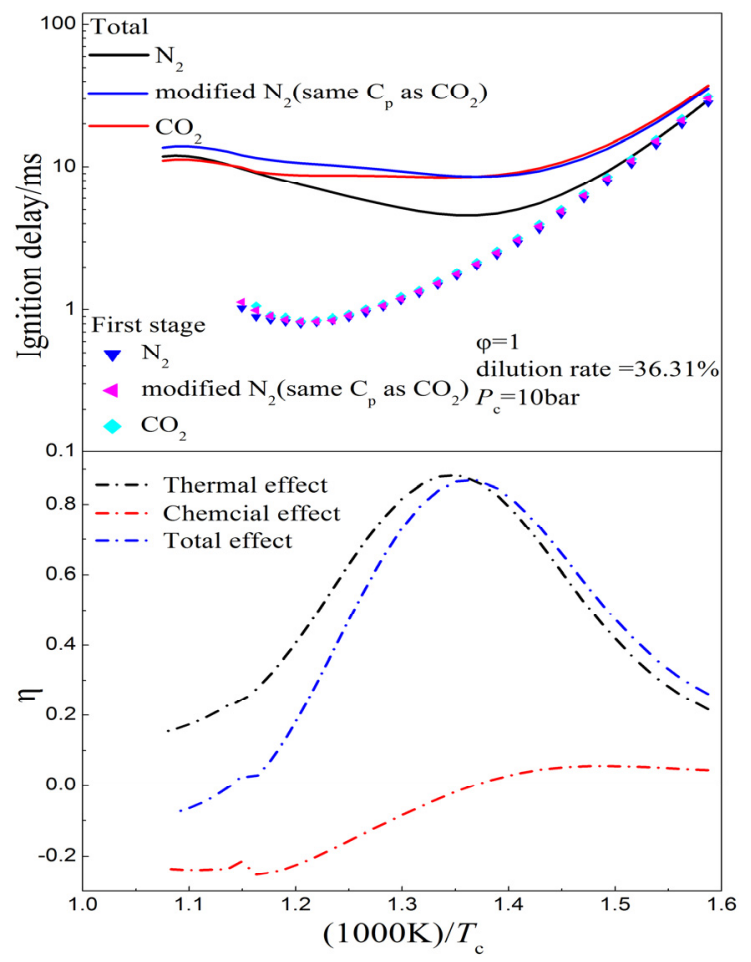

Figure 13. Comparison of the thermal and chemical effects of $\mathrm{CO}_{2}$ on the first-stage and total ignition delays.

It is seen from Figure 13 that the thermal effect of $\mathrm{CO}_{2}$ has a positive (increasing) effect on the total ignition delay due to its higher heat capacity compared to $\mathrm{N}_{2}$, which is opposite to that of Ar. The chemical effect of $\mathrm{CO}_{2}$ also has a positive (increasing) effect on the total ignition delay at the 
compressed temperature below $730 \mathrm{~K}$, and then the chemical effect of $\mathrm{CO}_{2}$ starts to decrease the total ignition delay. Moreover, the chemical effect of $\mathrm{CO}_{2}$ becomes pronounced in the NTC region and ultimately the chemical effect exceeds the thermal effect at the compressed temperature higher than $880 \mathrm{~K}$. Additionally, from Figures 12 and 13, the conclusion can be drawn that, compared to Ar, the chemical effect of $\mathrm{CO}_{2}$ is more pronounced at a high compressed temperature due to its high collision coefficients; moreover, $\mathrm{CO}_{2}$ acts as a reactant in some elementary reactions $[1,8]$.

From the above analysis we can conclude that the thermal effects of buffer gas composition is the dominant factor in the low temperature region and NTC region, the chemical effects become pronounced in the NTC region, and the chemical effect of $\mathrm{CO}_{2}$ exceeds the thermal effect at the compressed temperature higher than $880 \mathrm{~K}$.

\subsection{Dilution Effects of Buffer Gas Composition}

Figure 14 shows the effects of the $\mathrm{N}_{2}$ dilution ratio ranging from $36.31 \%$ to $55.04 \%$ on the first-stage and total ignition delays for both experimental and simulation results. The Zhao DME mechanism used in the simulation reproduces the trends of the total ignition delay well. Similar to the trends in Figure 5, the first-stage ignition delay is consistently over-predicted, especially at high compressed temperatures. As seen in Figure 14, the first-stage ignition delay increases slightly with an increasing $\mathrm{N}_{2}$ dilution ratio due to the fact that the compressed temperature is the dominant factor in the first-stage ignition [38]. However, a significant increase in the total ignition delay is observed. Figure 15 shows the variation of pressure rise during the first-stage ignition with $\mathrm{N}_{2}$ dilution ratio and compressed temperature for both experimental and simulation results. The general trends of pressure rise during the first-stage ignition in experiments are numerically reproduced well.

As seen in Figure 15, the heat release (represented by pressure rise) during the first-stage ignition decreases with increasing $\mathrm{N}_{2}$ dilution ratio. As we all know, the number of radicals created in the first-stage ignition dominates the second-stage ignition. The concentration of DME and $\mathrm{O}_{2}$ decreases with increasing $\mathrm{N}_{2}$ dilution ratio, then a slower first-stage ignition occurs, resulting in smaller heat release and radicals' accumulation. The second-stage ignition delay increases with decreasing radicals. As a result, the total ignition delay increases drastically. Additionally, the heat release during the first-stage ignition approximately tends to decrease linearly as compressed temperature increases. Moreover, a smaller difference in the heat release during the first-stage ignition among different $\mathrm{N}_{2}$ dilution ratios is observed at high compressed temperatures.

It is also seen from Figure 14 that both the measurements and model predictions reveal NTC behavior of the total ignition delay in the temperature range studied. Moreover, the NTC behavior of total ignition delay becomes more pronounced at high $\mathrm{N}_{2}$ dilution ratio. It is well known that, in general, the ratio of reactions forming alkylperoxy radicals $\left(\mathrm{RO}_{2}\right)$ to reactions forming alkyl radicals $(\mathrm{R})$ dictates the NTC behavior [13]. The concentration of $\mathrm{O}_{2}$ decreases with increasing $\mathrm{N}_{2}$ dilution ratio, shifting the ratio towards R formation. As a result, the NTC region moves to a lower compressed temperature, that is, the NTC behavior becomes pronounced. 


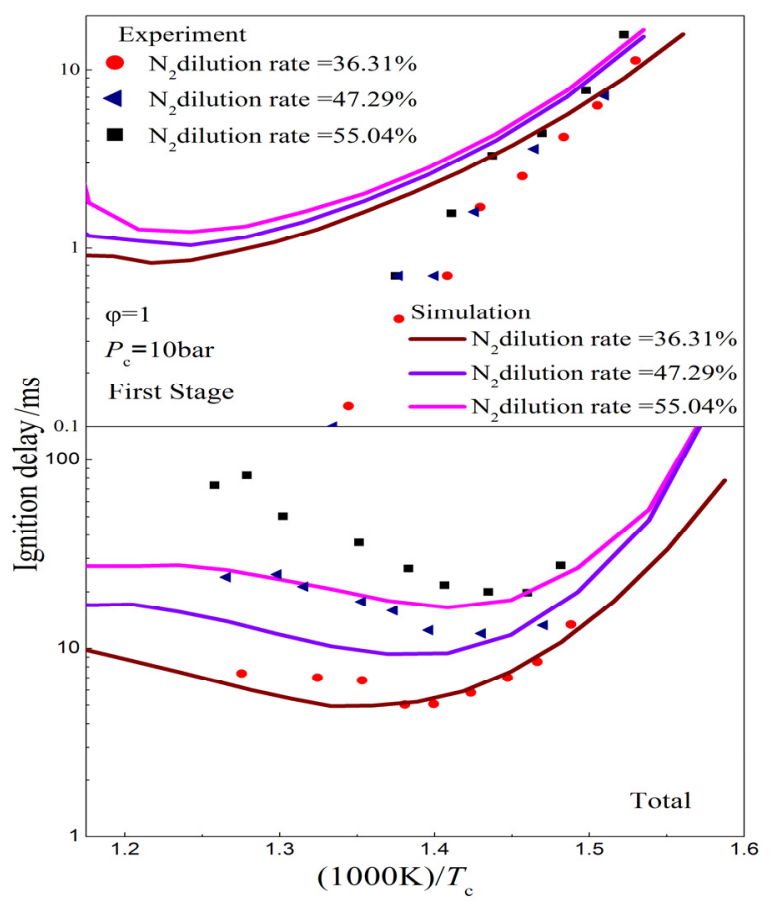

Figure 14. Experimental and simulation results of effects of $\mathrm{N}_{2}$ dilution ratio on the first-stage and total ignition delays.

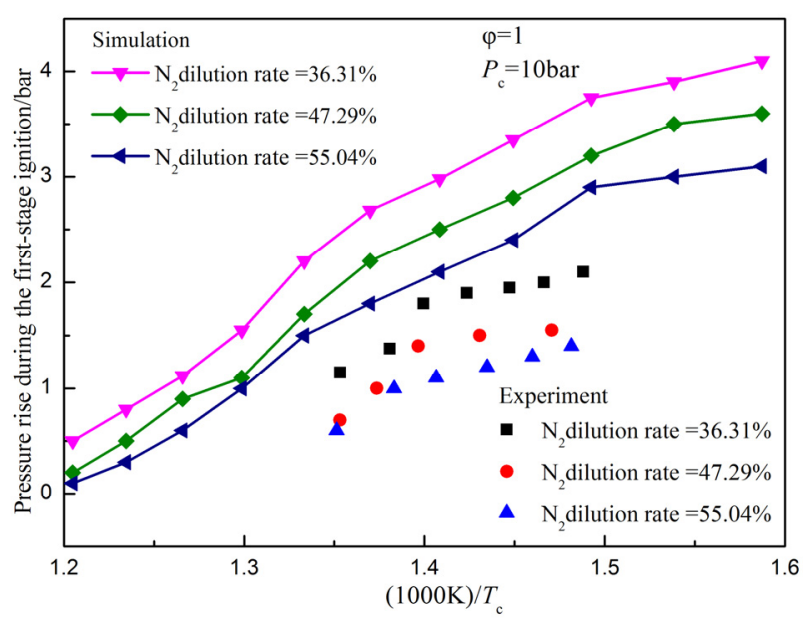

Figure 15. Experimental and simulation results of effects of $\mathrm{N}_{2}$ dilution ratio on pressure rise during the first-stage ignition.

A comparison of experimental and simulation results of $\mathrm{N}_{2}$ dilution ratio proves that the Zhao DME mechanism can predict the ignition delays well at different dilution ratios. Consequently, simulations of effects of Ar dilution ratio and $\mathrm{CO}_{2}$ dilution ratio on the ignition delays are conducted. As seen in Figures 16 and 17, the simulation results of $\mathrm{Ar}$ and $\mathrm{CO}_{2}$ reveal similar trends to that of $\mathrm{N}_{2}$ shown in Figure 14. Additionally, compared to $\mathrm{N}_{2}$ and Ar, NTC behavior of the total ignition delay of $\mathrm{CO}_{2}$ is not prominent.

Figure 18 shows the simulation results of heat release during the first-stage ignition for $\mathrm{Ar}$ and $\mathrm{CO}_{2}$, and the simulation results of heat release for $\mathrm{N}_{2}$ are also presented. 


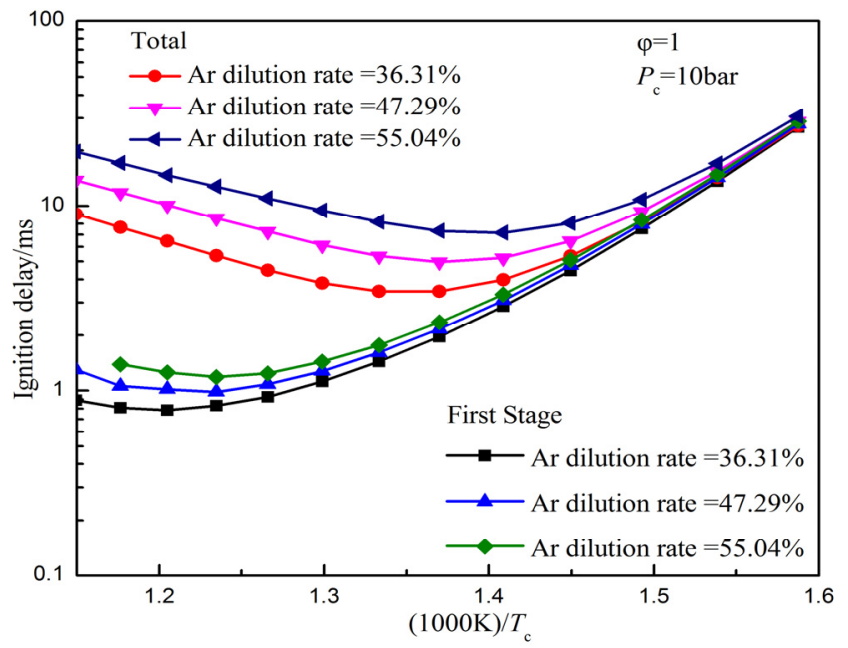

Figure 16. Simulation results of Ar dilution ratio on the first-stage and total ignition delays.

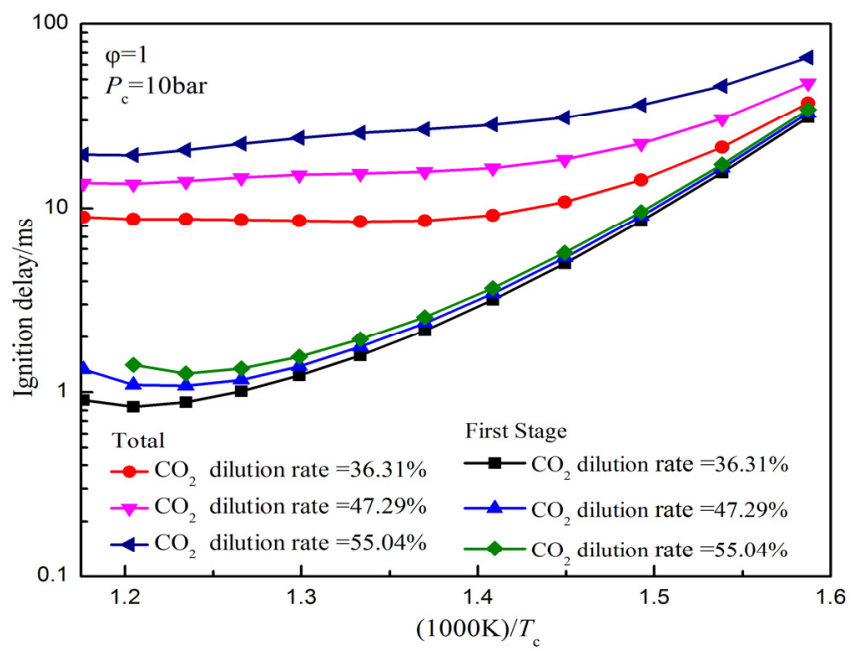

Figure 17. Simulation results of $\mathrm{CO}_{2}$ dilution ratio on the first-stage and total ignition delays.

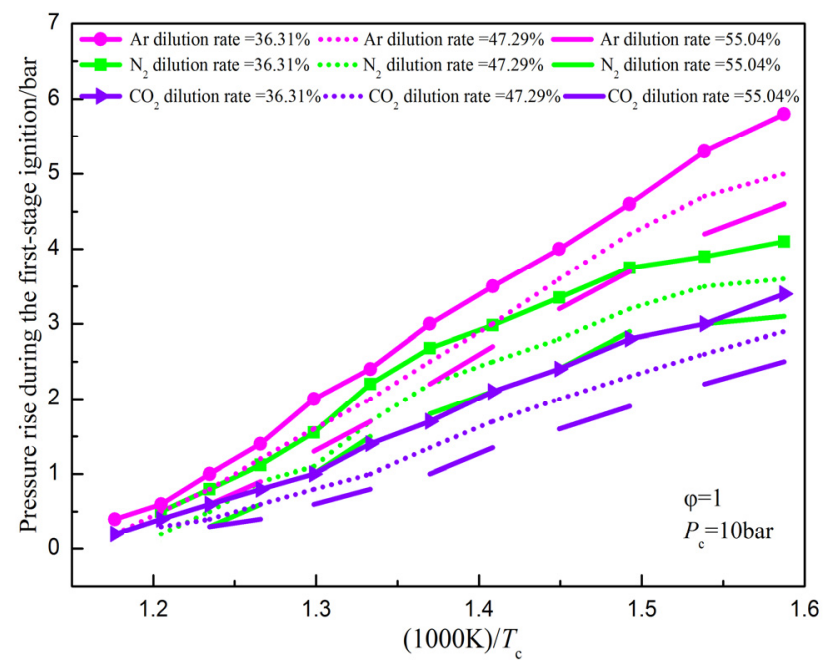

Figure 18. Simulation results of the effects of dilution ratio and buffer gas composition on pressure rise during the first-stage ignition. 
As seen in Figure 18, simulation results of the heat release during first-stage ignition for $\mathrm{Ar}$ and $\mathrm{CO}_{2}$ reveal the similar trends to that of $\mathrm{N}_{2}$. It is also noted that at the same compressed temperature, the magnitudes of heat release rank $\mathrm{Ar}$ as the highest, $\mathrm{N}_{2}$ second, and $\mathrm{CO}_{2}$ as the lowest, which is mainly caused by the differences in the buffer gas heat capacity. Thus, we can draw the conclusion that the heat release during the first-stage ignition is also sensitive to the buffer gas composition. Additionally, the buffer gas composition has a larger impact on heat release during the first-stage ignition at a low compressed temperature.

\section{Conclusions}

Experimental and numerical studies are performed to investigate the thermal, chemical and dilution effects of buffer gas composition on autoignition of DME. The following conclusions can be drawn:

(1) Both experimental and simulation results show that the buffer gas composition has little impact on the first-stage ignition delay. In the low temperature region, the effects of buffer gas composition on the total ignition delay are also negligible. However, compared to $\mathrm{N}_{2}$, the $\mathrm{N}_{2} / \mathrm{Ar}$ $(50 \% / 50 \%)$ mixture reduces the total ignition delay by $31 \%$ and $14 \%$ in the NTC region for experimental and simulation data, respectively.

(2) For ignition delays of $\mathrm{N}_{2}$ and the $\mathrm{Ar} / \mathrm{CO}_{2}(61.2 \% / 38.8 \%)$ mixture, experimental results show that the chemical effects have little impact on the first-stage and total ignition delays in the conditions studied, whereas the simulation results show that the chemical effects become pronounced at a compressed temperature higher than $770 \mathrm{~K}$.

(3) The simulation results using pure $\mathrm{N}_{2}, \mathrm{Ar}$ and $\mathrm{CO}_{2}$ as buffer gases show that the thermal effects are the dominant factor in a low temperature and NTC region. The chemical effects become pronounced in the NTC region, and the chemical effect of $\mathrm{CO}_{2}$ exceeds the thermal effect at a compressed temperature higher than $880 \mathrm{~K}$.

(4) With increasing buffer gas dilution ratio, the first-stage ignition delay slightly increases, but the total ignition delay has a significant increase due to the differences in heat release during first-stage ignition for different dilution ratios. The NTC behavior of total ignition delay becomes more pronounced at a high dilution ratio. The heat release during the first-stage ignition decreases with increasing buffer gas dilution ratio. Moreover, the heat release during first-stage ignition is sensitive to buffer gas composition.

\section{Acknowledgments}

This work was sponsored by the National Natural Science Foundation of China (Grant No. 51376011), the Beijing Natural Science Foundation Program (Grant No. 3152005), the Scientific Research Key Program of Beijing Municipal Commission of Education (Grant No. KZ201410005003), and the Project of Thirteenth Scientific Research Foundation for Graduate Students in Beijing University of Technology (Grant No. ykj-2014-11040). 


\section{Author Contributions}

Zhicheng Shi wrote the main body of the paper. Hongguang Zhang and Hao Liu revised the paper. Haitao Lu, Jiazheng Li and Xiang Gao performed the experiments. All authors read and approved the manuscript.

\section{Conflicts of Interest}

The authors declare no conflict of interests.

\section{Nomenclature}

$\begin{array}{ll}P_{0} & \text { Initial pressure (bar) } \\ T_{0} & \text { Initial temperature }(\mathrm{K}) \\ P_{\mathrm{c}} & \text { Compressed pressure (bar) } \\ T_{\mathrm{c}} & \text { Compressed temperature }(\mathrm{K}) \\ \Delta \tau_{\mathrm{t}, \mathrm{Ar}} & \text { Thermal effect index of } \mathrm{Ar} \\ \Delta \tau_{\mathrm{t}, \mathrm{CO} 2} & \text { Thermal effect index of } \mathrm{CO}_{2} \\ \Delta \tau_{\mathrm{c}, \mathrm{Ar}} & \text { Chemical effect index of } \mathrm{Ar} \\ \Delta \tau_{\mathrm{c}, \mathrm{CO} 2} & \text { Chemical effect index of } \mathrm{CO}_{2}\end{array}$

\section{Greek letters}

$\begin{array}{ll}\varphi & \text { Equivalence ratio } \\ \gamma & \text { Ratio of specific heat } \\ \varepsilon & \text { Compression ratio } \\ \tau_{1} & \text { First-stage ignition delay } \\ \tau_{2} & \text { Second-stage ignition delay } \\ \tau & \text { Total ignition delay }\end{array}$

\section{Acronyms}

$\begin{array}{ll}\text { DME } & \text { Dimethyl ether } \\ \text { RCM } & \text { Rapid compression machine } \\ \text { NTC } & \text { Negative temperature coefficient } \\ \text { EGR } & \text { Exhaust gas recirculation } \\ \text { ICE } & \text { Internal combustion engine } \\ \text { HCCI } & \text { Homogeneous charge compression ignition } \\ \text { PCCI } & \text { Premixed charge compression ignition } \\ \text { IMEP } & \text { Indicated mean effective pressure } \\ \text { TDC } & \text { Top dead center } \\ \text { ST } & \text { Shock tube }\end{array}$

\section{References}

1. Ladommatos, N.; Abdelhalim, S.M.; Zhao, H.; Hu, Z. The effects of carbon dioxide in exhaust gas recirculation on diesel engine emissions. Proc. Inst. Mech. Eng. 1998, 212, 25-42. 
2. Pierpont, D.A.; Montgomery, D.T.; Reitz, R.D. Reducing particulate and $\mathrm{NO}_{x}$ using multiple injections and EGR in a DI diesel. SAE Tech. Pap. 1995, doi:10.4271/950217.

3. Li, W.F.; Liu, Z.C.; Wang, Z.S.; Xu, Y. Experimental investigation of the thermal and diluent effects of EGR components on combustion and $\mathrm{NO}_{x}$ emissions of a turbocharged natural gas SI engine. Energy Convers. Manag. 2014, 88, 1041-1050.

4. Sjöberg, M.; Dec, J.E. Effects of EGR and its constituents on HCCI autoignition of ethanol. Proc. Combust. Inst. 2011, 33, 3031-3038.

5. Al-Qurashi, K.; Lueking, A.D.; Boehman, A.L. The deconvolution of the thermal, dilution, and chemical effects of exhaust gas recirculation (EGR) on the reactivity of engine and flame soot. Combust. Flame 2011, 158, 1696-1704.

6. Cairns, A.; Blaxill, H.; Irlam, G. Exhaust gas recirculation for improved part and full load fuel economy in a turbocharged gasoline engine. SAE Tech. Pap. 2006, doi:10.4271/2006-01-0047.

7. Kiplimo, R.; Tomita, E.; Kawahara, N.; Zhou, S.Y.; Yokobe, S. Effects of injection pressure, timing and EGR on combustion and emissions characteristics of diesel PCCI engine. SAE Tech. Pap. 2011, doi:10.4271/2011-01-1769.

8. Ladommatos, N.; Abdelhalim, S.M.; Zhao, H.; Hu, Z. The dilution, chemical, and thermal effects of exhaust gas recirculation on diesel engine emissions-Part 2: Effects of carbon dioxide. SAE Tech. Pap. 1996, doi:10.4271/961167.

9. Shen, H.-P.S.; Vanderover, J.; Oehlschlaeger, M.A. A shock tube study of iso-octane ignition at elevated pressures: The influence of diluent gases. Combust. Flame 2008, 155, 739-755.

10. Würmel, J.; Silke, E.J.; Curran, H.J.; Ó Conaire, M.S.; Simmie, J.M. The effect of diluent gases on ignition delay times in the shock tube and in the rapid compression machine. Combust. Flame 2007, 151, 289-302.

11. Yu, Y.; Vanhove, G.; Griffiths, J.F.; Ferrières, S.D.; Pauwels, J.-F. Influence of EGR and syngas components on the autoignition of natural gas in a rapid compression machine: A detailed experimental study. Energy Fuels 2013, 27, 3988-3996.

12. Davidson, D.F.; Hanson, R.K. Interpreting shock tube ignition data. Int. J. Chem. Kinet. 2004, 36, 510-523.

13. Wagnon, S.W.; Wooldridge, M.S. Effects of buffer gas composition on autoignition. Combust. Flame 2014, 161, 898-907.

14. Arcoumanis, C.; Bae, C.; Crookes, R.; Kinoshita, E. The potential of di-methyl ether (DME) as an alternative fuel for compression-ignition engines: A review. Fuel 2008, 87, 1014-1030.

15. Chen, Z.Y.; Tang, C.L.; Fu, J.; Jiang, X.; Li, Q.Q.; Wei, L.J.; Huang, Z.H. Experimental and numerical investigation on diluted DME flames: Thermal and chemical kinetic effects on laminar flame speeds. Fuel 2012, 102, 567-573.

16. Zhang, B.; Shen, X.B.; Pang, L. Effects of argon/nitrogen dilution on explosion and combustion characteristics of dimethyl ether-air mixtures. Fuel 2015, 159, 646-652.

17. Jamsran, N.; Lim, O.; Iida, N. A computational study of the effects of EGR and intake-pressure boost on DME autoignition characteristics over wide ranges of engine speed. SAE Int. J. Fuels Lubr. 2014, 7, 207-223. 
18. Zhao, Y.W.; Wang, Y.; Li, D.C.; Lei, X.; Liu, S.H. Combustion and emission characteristics of a DME (dimethyl ether)-diesel dual fuel premixed charge compression ignition engine with EGR (exhaust gas recirculation). Energy 2014, 72, 608-617.

19. Pedersen, T.D.; Schramm, J.; Yanai, T.; Sato, Y. Controlling the heat release in HCCI combustion of DME with methanol and EGR. SAE Tech. Pap. 2010, doi:10.4271/2010-01-1489.

20. Liu, D.; Santner, J.; Togbé, C.; Felsmann, D.; Koppmann, J.; Lackner, A.; Yang, X.L.; Shen, X.B.; Ju, Y.G.; Kohse-Höinghaus, K. Flame structure and kinetic studies of carbon dioxide-diluted dimethyl ether flames at reduced and elevated pressures. Combust. Flame 2013, 160, 2654-2668.

21. Li, Z.H.; Wang, W.J.; Huang, Z.; Oehlschlaeger, M.A. Dimethyl ether autoignition at engine-relevant conditions. Energy Fuels 2013, 27, 2811-2817.

22. Liu, H.; Zhang, H.G.; Shi, Z.C.; Lu, H.T.; Zhao, G.Y.; Yao, B.F. Performance characterization and auto-ignition performance of a rapid compression machine. Energies 2014, 7, 6083-6104.

23. Werler, M.; Cancino, L.R.; Schiessl, R.; Maas, U.; Schulz, C.; Fikri, M. Ignition delay times of diethyl ether measured in a high-pressure shock tube and a rapid compression machine. Proc. Combust. Inst. 2015, 35, 259-266.

24. Lee, D.; Hochgreb, S. Rapid compression machines: Heat transfer and suppression of corner vortex. Combust. Flame 1998, 114, 531-545.

25. Affleck, W.S.; Thomas, A. An opposed piston rapid compression machine for preflame reaction studies. Proc. Inst. Mech. Eng. 1968, 183, 365-387.

26. Gupta, S.B.; Bihari, B.; Sekar, R.; Klett, G.M.; Ghaffarpour, M. Ignition characteristics of methane-air mixtures at elevated temperatures and pressures. SAE Tech. Pap. 2005, doi:10.4271/2005-01-2189.

27. Allen, C.; Mittal, G.; Sung, C.-J.; Toulson, E.; Lee, T. An aerosol rapid compression machine for studying energetic-nanoparticle-enhanced combustion of liquid fuels. Proc. Combust. Inst. 2011, 33, 3367-3374.

28. Sung, C.-J.; Curran, H.J. Using rapid compression machines for chemical kinetic studies. Prog. Energy Combust. Sci. 2014, 44, 1-18.

29. Di Sante, R. Measurements of the auto-ignition of n-heptane/toluene mixture using a rapid compression machine. Combust. Flame 2012, 159, 55-63.

30. Mittal, G.; Sung, C.-J. A rapid compression machine for chemical kinetics studies at elevated pressures and temperatures. Combust. Sci. Tech. 2007, 179, 497-530.

31. Zhao, Z.W.; Chaos, M.; Kazakov, A.; Dryer, F.L. Thermal decomposition reaction and a comprehensive kinetic model of dimethyl ether. Int. J. Chem. Kinet. 2008, 40, 1-18.

32. Dagaut, P.; Boettner, J.-C.; Cathonnet, M. Chemical kinetic study of dimethylether oxidation in a jet stirred reactor from 1 to 10 ATM: Experiments and kinetic modeling. Symp. Int. Combust. 1996, 26, 627-632.

33. Pan, L.; Hu, E.J.; Tian, Z.M.; Yang, F.Y.; Huang, Z.H. Experimental and kinetic study on ignition delay times of dimethyl ether at high temperatures. Energy Fuels 2015, 29, 3495-3506.

34. Daly, C.A.; Simmie, J.M.; Würmel, J.; Djebaïli, N.; Paillard, C. Burning velocities of dimethyl ether and air. Combust. Flame 2001, 125, 1329-1340.

35. Mittal, G.; Chaos, M.; Sung, C.-J.; Dryer, F.L. Dimethyl ether autoignition in a rapid compression machine: Experiments and chemical kinetic modeling. Fuel Process. Technol. 2008, 89, 1244-1254. 
36. Di, H.S.; He, X.; Zhang, P.; Wang, Z.; Wooldridge, M.S.; Law, C.K.; Wang, C.P.; Shuai, S.J.; Wang, J.X. Effects of buffer gas composition on low temperature ignition of iso-octane and n-heptane. Combust. Flame 2014, 161, 2531-2538.

37. Wang, Y.; Yang, Z.; Yang, X.; Han, D.; Huang, Z.; Lu, X.C. Experimental and modeling studies on ignition delay times of methyl hexanoate/ $n$-butanol blend fuels at elevated pressures. Energy Fuels 2014, 28, 5515-5522.

38. Guang, H.Y.; Yang, Z.; Huang, Z.; Lu, X.C. Experimental study of $n$-heptane ignition delay with carbon dioxide addition in a rapid compression machine under low-temperature conditions. Chin. Sci. Bull. 2012, 57, 3953-3960.

(C) 2015 by the authors; licensee MDPI, Basel, Switzerland. This article is an open access article distributed under the terms and conditions of the Creative Commons Attribution license (http://creativecommons.org/licenses/by/4.0/). 